\title{
KUALITAS DIET DAN HUBUNGANNYA DENGAN PENGETAHUAN GIZI, STATUS SOSIAL EKONOMI, DAN STATUS GIZI
}

\author{
(Diet Quality and Association with Nutrition Knowledge, Socio-economic Status, and Nutrition Status)
}

\author{
Nurul Muslihah¹, Sri Winarsih², Soemardini², AS Zakaria1, dan Zainudiin ${ }^{1}$ \\ 1Jurusan Ilmu Gizi, Fakultas Kedokteran, Universitas Brawijaya, Malang \\ 2Jurusan Pendidikan Kedokteran, Fakultas Kedokteran, Universitas Brawijaya, Malang
}

\begin{abstract}
The objective of study was to assess the diet quality and its relation to nutrition knowledge, body mass index (BMI), and socio economic status (SES) among adults person. The cross sectional study was conducted with 100 adults aged $\geq 25$ years old from Kedung Kandang sub district, Malang. Dietary quality was assessed using two non-consecutive 24-h dietary recalls and semi quantitative FFQ. Nutrition knowledge questionnaire was modified from Parmenter and Wardle. The most subjects were middle SES and the BMI were normal and overweight. The average of diet quality score was $7.14 \pm 1.96$ with dietary diversity score $1.93 \pm 0.43$; micronutrient adequacy score 2.3 \pm 1.4 ; prevention NCD score $2.87 \pm 0.92$. Nutrition knowledge score was $43.3 \pm 24.6$ with dietary recommendation $9.3 \pm 3.6$; sources of nutrients $14 \pm 11.5$; choosing foods $6.3 \pm 4.9$; dietdisease relationships $13.7 \pm 8.6$. Nutrition knowledge score was no correlation with BMI, dietary diversity, prevention NCD score, but positively associated with SES, quality diet, micronutrient adequacy score. SES was no associated with BMI and quality diet index. Dietary diversity score was associated with BMI. Diet quality score was associated with nutrition knowledge but no correlation with BMI and SES. The conclusion is diet quality and nutrition knowledge was still poor and not correlated with BMI and SES, but only nutrition knowledge score.
\end{abstract}

Keywords: diet quality, nutrition knowledge, socio economic status

\begin{abstract}
ABSTRAK
Tujuan penelitian mengkaji kualitas diet dan hubungannya dengan pengetahuan gizi, indek massa tubuh (IMT), dan status sosial ekonomi (SSE) pada orang dewasa. Rancangan penelitian menggunakan cross sectional study pada 100 orang dewasa usia $\geq 25$ tahun dari Kecamatan Kedung Kandang, Malang. Kualitas makanan diukur dengan 24-hour recall selama dua hari yang tidak berurutan dan semi quantitative FFQ, kuesioner pengetahuan gizi terstruktur dimodifikasi dari Parmenter dan Wardle. Umumnya subjek dengan SSE menengah dan IMT normal dan overweight. Rata-rata skor kualitas diet adalah $7.14 \pm 1.96$ dengan skor dietary diversity $1.93 \pm 0.43$; skor kecukupan zat gizi mikro $2.3 \pm 1.4$; skor pencegahan penyakit tidak menular (PTM) $2.87 \pm 0.92$. Skor pengetahuan gizi $43.3 \pm 24.6$ meliputi rekomendasi makanan 9.3 \pm 3.6 ; sumber zat gizi $14 \pm 11.47$; pemilihan makanan 6.3 \pm 4.96 ; hubungan diet-penyakit $13.7 \pm 8.6$. Skor pengetahuan gizi tidak berhubungan dengan IMT, skor dietary diversity dan skor PTM, namun berhubungan posistif dengan SSE, total skor kualitas diet dan skor kecukupan zat gizi mikro. SSE tidak berhubungan dengan IMT dan semua aspek indek kualitas diet. IMT hanya berhubungan dengan skor dietary diversity. Sementara skor kualitas diet berhubungan dengan pengetahuan gizi namun tidak dengan IMT dan SSE. Kesimpulan adalah skor kualitas diet dan pengetahuan gizi masih rendah. Kualitas diet hanya berhubungan dengan pengetahuan gizi namun tidak dengan IMT dan SSE.
\end{abstract}

Kata kunci: kualitas diet, pengetahuan gizi, status sosial ekonomi

"Korespondensi: Departemen Gizi Masyarakat, Fakultas Ekologi Manusia (FEMA), Institut Pertanian Bogor, Bogor 16680. Email: nurul_muslihah@yahoo.com 
Muslihah dkk.

\section{PENDAHULUAN}

Hampir semua negara berkembang termasuk Indonesia, saat ini mengalami transisi epidemiologi yaitu prevalensi penyakit infeksi masih tetap tinggi sementara penyakit tidak menular mulai terus meningkat dengan tajam. Pada saat bersamaan juga berlangsung transisi gizi dengan adanya perubahan pola makan tradisional ke makanan yang tinggi lemah jenuh, gula, makanan siap saji dan rendah serat (Popkin 2002). Perubahan ini bersamaan dengan perubahan gaya hidup yang berhubungan dengan perkembangan ekonomi, urbanisasi yang cepat dari desa ke kota dan globalisasi dengan meningkatkan konsumsi tembakau, makanan yang tidak sehat, kurangnya aktivitas fisik yang merupakan faktor determinan penting dalam kejadian penyakit tidak menular (PTM).

Rendahnya konsumsi buah dan sayur adalah salah satu faktor risiko utama PTM selain meningkatnya tekanan darah, konsumsi tembakau, meningkatnya kolesterol total. Secara bersamaan faktor risiko utama dapat menyumbang hampir $80 \%$ kematian dari penyakit jantung dan stroke. Diet yang tidak sehat dengan ditandai rendahnya konsumsi buah dan sayur adalah salah satu faktor risiko perilaku yang dapat dimodifikasi (WHO 2002). Kunci utama untuk pengendalian epidemik global dari PTM melalui pencegahan primer dengan melakukan identifikasi faktor risiko utama dari penyakit tersebut.

Pengetahuan gizi akan memengaruhi pemilihan makanan pada orang dewasa, hal ini dapat dilihat dari perbedaan perilaku makan, walaupun hasil penelitian masih belum konsisten untuk melihat hubungannya. Salah satu alasan dari ketidakkonsistenan hubungan pengetahuan gizi dan perilaku makan adalah pertanyaan dari pengetahuan yang diukur. Pertanyaan kuesioner dari hasil modifikasi kuesioner pengetahuan gizi yang telah dikembangkan oleh Parmenter and Wardle (1999), meliputi rekomendasi makananan dengan test-retest reliability (0.8); sumber zat gizi (0.94); pemilihan makanan setiap hari (0.87); hubungan diet dan penyakit (0.97); dan total tes-retest reliability adalah (0.98).

Kualitas diet penting bagi kesehatan. Pedoman gizi seimbang biasanya merekomendasikan peningkatan keragaman makanan dalam kelompok makanan dan dapat menjamin kecukupan zat gizi mikro (WHO/FAO 1996). Kualitas diet dapat juga diukur berdasarkan kepatuhan dalam pedoman gizi seimbang atau rekomendasi untuk kesehatan seperti pencegahan penyakit kronis yang berhubungan dengan makanan yang diformulasikan oleh WHO (WHO/FAO 2003). Penilaian kualitas diet di populasi pada berbagai tahap berbeda dari transisi gizi akan menjadi penting sebagai sumber informasi untuk makanan yang berkaitan dengan transisi (Kim et al. 2003). Indeks kualitas makanan atau diet berdasar- kan keragaman makanan (dietary diversity), kecukupan zat gizi mikro (micronutrient adequacy), dan pemenuhan rekomendasi WHO untuk pencegahan penyakit kardiovaskular (Ponce 2006).

Konsumsi asupan sayuran dan buah yang rendah dapat memberikan kontribusi beban untuk terjadinya penyakit kardiovaskular (85\%) dan kanker (15\%) (Kim et al. 2003). Rendahnya asupan sayuran dan buah juga diperkirakan dapat menyebabkan kanker gastrointestinal (19\%), penyakit jantung (31\%) dan stroke (11\%) (WHO 2002). Konsumsi sedikitnya $400 \mathrm{~g}$ buah-buahan dan sayur per hari merupakan rekomendasi untuk mencegah penyakit kronis yang berhubungan dengan makanan atau diet (WHO/FAO 2003).

Kajian faktor-faktor yang dapat memengaruhi kualitas diet perlu dilakukan berdasarkan status sosial ekonomi dan status gizi. Kualitas diet orang dewasa dipengaruhi oleh ketersediaan dan pemilihan terhadap bahan pangan dan hal ini berhubungan dengan aspek pengetahuan gizi. Hubungan pengetahuan gizi dan kualitas diet akan memberikan tambahan informasi dalam upaya strategi komunikasi untuk perubahan perilaku makan. Kualitas diet juga mungkin berbeda menurut status gizi orang dewasa. Gambaran ini dapat memberikan informasi awal dalam upaya menyusun strategi perilaku sehat dalam upaya pencegahan terhadap penyakit tidak menular.

Tujuan penelitian ini adalah untuk mengkaji kualitas diet dan hubungannya dengan pengetahuan gizi, status sosial ekonomi (SSE), dan indeks massa tubuh (IMT) pada orang dewasa. Sedangkan tujuan khusus penelitian ini adalah menilai skor indeks kualitas diet dan pengetahuan gizi; mengkaji hubungan skor indeks kualitas diet dan pengetahuan gizi dengan SSE dan IMT.

\section{METODE}

\section{Desain, Tempat, dan Waktu}

Penelitian ini adalah observasional analitik dengan desain penelitian cross sectional. Waktu penelitian dari bulan Januari-Pebruari 2011. Penelitian ini dilaksanakan di Kecamatan Kedung Kandang, Kota Malang, Jawa Timur.

\section{Jumlah dan Cara Penarikan Subjek}

Populasi pada penelitian ini adalah seluruh orang dewasa baik laki-laki maupun perempuan usia $\geq 25$ tahun yang tinggal di Kota Malang. Pada usia tersebut sudah mulai memasuki masa dewasa dan faktor risiko terhadap PTM semakin besar. Unit sampling adalah rumah tangga. Kriteria inklusi subjek adalah orang dewasa usia 25 tahun ke atas pada rumah tangga yang terpilih dan bersedia menjadi subjek dengan menyetujui secara tertulis untuk ikut serta dalam penelitian. 
Pemilihan empat desa dari 12 desa di Kecamatan Kedung Kandang dengan metode Probability Proportional Size (PPS). Pemilihan rumah tangga yang mempunyai orang dewasa usia $\geq 25$ tahun dengan systematic random sampling. Besar subjek berdasarkan estimasi proporsi 47\% dengan presisi $10 \%$ dan tingkat kepercayaan 95\% dan jumlah total subjek 100 orang. Perhitungan subjek penelitian menggunakan rumus sebagai berikut:

$$
\mathrm{n}=\frac{\mathrm{Z}_{1-\mathrm{a} / 2}^{2} \times P(1-\mathrm{P})}{\mathrm{d}^{2}}
$$

\section{Jenis dan Cara Pengumpulan Data}

Peubah atau variabel yang dikumpulkan adalah data status sosial ekonomi meliputi tingkat pendidikan, status pekerjaan, dan rasio pendapatan dan pengeluaran pangan, pengetahuan gizi tentang rekomendasi zat gizi dari ahli gizi, sumber-sumber zat gizi, pemilihan makanan yang sehat dan hubungan antara diet dan penyakit, status gizi orang dewasa dengan menggunakan IMT dan kualitas diet.

Pengumpulan data sosial ekonomi dan demografi dengan kuesioner yang terstruktur, kuesioner tentang pengetahuan gizi modifikasi yang sudah dikembangkan oleh Parmenter and Wardle (1999). Skor SSE berdasarkan tingkat pendidikan (tidak sekolah/tidak tamat $S D$ skor $=0$, tamat $S D=1$, tamat $\mathrm{SMP} / \mathrm{SMA}=2$, lulusan diploma=3, lulusan sarjana=4); pekerjaan (tidak bekerja=0, petani=1, buruh=2, pedagang/wiraswasta=3,PNS/ABRI/pensiunan/karyawan swasta $=4$ ); rasio pengeluaran pangan dengan pendapatan 0.76-1.00 (skor 1), 0.51-0.75 (skor 2), 0-0.25 (skor 3). Skor akhir SSE dari komposit tiga variabel adalah rendah (total skor $\leq 3$ ), sedang $(4-8)$ dan tinggi $(\geq 9)$. Indeks komposit ini modifikasi yang dikembangkan oleh Ponce (2006).

Skor pengetahuan gizi berdasarkan empat kelompok pertanyaan meliputi rekomendasi makanan (skor maks 22); sumber-sumber zat gizi (skor maks 43); pemilihan makanan yang tepat setiap hari (skor maks 20); dan hubungan diet dan penyakit (skor maks 46) total skor 131. Penilaian status gizi subjek berdasarkan IMT $\left(\mathrm{kg} / \mathrm{m}^{2}\right)$. Klasifikasi status gizi dengan IMT adalah <18.5 (kurang gizi); 18.5-24.99 (normal); 25-29.99 (overweight); $\geq 30$ (obesitas).

Kualitas diet atau konsumsi makanan diolah dari hasil 24-hour recall selama dua hari yang tidak berurutan dan FFQ menggunakan Program Nutrisurvey. Kualitas diet menggunakan tiga indeks meliputi keragaman makanan dari data rata-rata frekuensi harian dari FFQ dengan skor maks 4 dari 9 kelompok makanan dengan kriteria konsumsi 0-2 jenis kelompok makanan (skor 1), 3-5 jenis (skor 2), 6-7 jenis (skor 3), 8-9 jenis (skor 4) (Ruel 2000); kecukupan zat gizi mikro dari 75 \% AKG dari 11 vitamin dan mineral (kalsium, besi, magnesium, seng, vitamin A, a-tocopherol, vitamin C, tiamin, riboflavin, vitamin B6, asam folat) dengan skor maksimal
11 karena tidak dapat dihitung asupan vitamin B3 dan B12 (IOM. 1998; 2000); dan rekomendasi WHO untuk pencegahan penyakit tidak menular dengan skor maksimal enam yaitu buah \& sayur $\geq 400$ g; protein $\geq 10 \%$ asupan energi; total lemak $<30 \%$ asupan energi; asam lemak jenuh $<10 \%$ asupan energi; PUFA 6-10\% asupan energi; kolesterol <300 mg; sukrosa $<10 \%$ asupan energi; serat $\geq 25 \mathrm{~g}$, (WHO 2000). Sementara data asam lemak jenuh ( $<10 \%$ asupan energi) dan asupan sukrosa ( $<10 \%$ asupan energi) tidak dapat dihitung karena tidak tersedia dalam daftar komposisi bahan makanan dalam program Nutrisurvey. Total skor untuk kualitas diet adalah 21

Penelitian ini mendapat ethical clearance dari Tim Etik Fakultas Kedokteran Universitas Brawijaya. Semua subjek yang terlibat dalam penelitian ini mengisi informed consent sebagai bentuk pernyataan persetujuan menjadi subjek pada penelitian ini. Sebelum menandatangani informed consent, subjek diberi penjelasan tentang tujuan penelitian, keterlibatan dalam penelitian, manfaat, dan dampak yang akan didapat subjek.

\section{Pengolahan dan Analisis Data}

Data kuesioner diolah dengan program SPSS versi 13.0 dan dan disajikan dalam bentuk deskriptif dan uji korelasi. Sementara data pengukuran antropometri diolah dengan WHO Antro 2005 dan data pengukuran dietetik diolah dengan Program Nutrisurvey. Data kontinu disajikan dalam ratarata \pm simpangan baku, sementara data ordinal atau nominal disajikan dalam persentase. Perbedaan data kontinu antara kelompok SSE dianalisa dengan one-way ANOVA. Sementara hubungan antara variabel skor kualitas diet dan pengetahuan gizi dianalisa dengan Uji Spearman. Hubungan antara skor kualitas diet dengan SSE dan status gizi karena data tidak normal walaupun sudah dilakukan transformasi data maka dianalisa dengan uji Spearman.

\section{HASIL DAN PEMBAHASAN}

\section{Karakteristik Demografi dan Sosio Ekonomi}

Rata-rata umur subjek adalah $44.7 \pm 13.41$ tahun dengan persentase terbesar pada kelompok 4064 tahun (50\%). SSE dengan indeks komposit tingkat pendidikan, pekerjaaan dan rasio pengeluaran pangan dengan pendapatan. Persentase subjek dengan skor SSE rendah (32.7\%), sedang (56.1\%), dan tinggi (11.2\%). Gambaran karakteristik demografi dan sosial ekonomi subjek dapat dilihat pada Tabel 1.

Berdasarkan karakteristik dan keadaan fisiologis dari orang dewasa perlu dilakukan perbandingan analisa pada kelompok dewasa pemula usia 25-39 tahun dan kelompok dewasa lanjut 40-64 tahun dan mulai dirancang sejak pemilihan subjek dengan kuota yang sama. Pemilihan subjek secara acak namun tidak memerhatikan umur telah menyebabkan 
Muslihah dkk.

Tabel 1. Karakteristik Demografi dan Sosial Ekonomi

\begin{tabular}{|c|c|c|c|}
\hline \multicolumn{2}{|r|}{ Karakteristik } & \multirow{2}{*}{$\frac{\text { Persentase (\%) }}{39.0}$} & \multirow[t]{2}{*}{ Rata-rata \pm SD } \\
\hline Umur (Tahun): & $25-39$ & & \\
\hline & $40-64$ & 50.0 & $44.7 \pm 13.41$ \\
\hline & $>64$ & 11.0 & \\
\hline \multirow[t]{2}{*}{ Jenis Kelamin: } & Laki-laki & 42.0 & - \\
\hline & Perempuan & 58.0 & - \\
\hline \multirow[t]{5}{*}{ Tingkat pendidikan: } & Tidak sekolah/tidak tamat SD & 30.0 & - \\
\hline & Tamat SD & 22.0 & - \\
\hline & Tamat SMP/SMA & 38.0 & - \\
\hline & Lulusan Diploma & 1.0 & - \\
\hline & Lulusan Sarjana & 9.0 & - \\
\hline \multirow[t]{5}{*}{ Pekerjaan: } & Tidak bekerja & 34.0 & - \\
\hline & Petani & 2.0 & - \\
\hline & Buruh & 7.0 & - \\
\hline & Pedagang/wiraswasta & 42.0 & - \\
\hline & PNS/ABRI/pensiunan/ karyawan swasta & 15.0 & - \\
\hline \multirow{3}{*}{$\begin{array}{l}\text { Pendapatan \& } \\
\text { Pengeluaran: }\end{array}$} & Pendapatan & - & $1304184 \pm 952812.36$ \\
\hline & Pengeluaran Pangan & - & $669948.98 \pm 399699.92$ \\
\hline & Rasio Pengeluaran Pangan:Pendapatan & - & $0.59 \pm 0.22$ \\
\hline \multirow{3}{*}{$\begin{array}{l}\text { Status Sosial } \\
\text { Ekonomi (SSE): }\end{array}$} & Rendah & 32.7 & \\
\hline & Menengah & 56.1 & \\
\hline & Tinggi & 11.2 & \\
\hline
\end{tabular}

rentang usia subjek sangat lebar walaupun separuh dari subjek berada pada rentang usia 40-64 tahun. Kelemahan penelitian karena rentang umur ini memengaruhi jumlah dan jenis makanan yang dikonsumsi dan pada akhirnya berdampak pada kualitas dietnya.

\section{Status Gizi}

Status gizi subjek berdasarkan IMT. Subjek umumnya mempunyai status gizi normal dengan IMT 18.5-24.99 (53\%) dan overweight 25-29.99 (38\%). Subjek dengan SSE tinggi tidak ada yang kurang gizi dan umumnya normal dan overweight. Tidak ada subjek dengan status gizi obes $\left(\geq 30 \mathrm{~kg} / \mathrm{m}^{2}\right)$.

\section{Pengetahuan Gizi}

Rata-rata skor pengetahuan gizi subjek masih sangat rendah dari skor maksimal (33.05\% atau 43.3 dari maksimal skor 131). Aspek rekomendasi makanan oleh ahli gizi mempunyai skor $42.27 \%$, sumbersumber zat gizi dengan skor $32.56 \%$, pemilihan makanan tiap hari dengan skor $31.5 \%$, dan hubungan diet dan penyakit mempunyai skor $33.05 \%$. Rata-rata skor pengetahuan gizi dapat dilihat pada Tabel 2. Terdapat perbedaan yang bermakna skor pengetahuan gizi antara kelompok berdasarkan status sosial ekonomi.

Pengetahuan gizi subjek masih sangat rendah (33.05\%) dan ini juga terjadi pada keempat aspek pengetahuan meliputi rekomendasi makanan menurut ahli gizi, sumber-sumber zat gizi, pemilihan makanan sehari dan hubungan diet dan penyakit. Pertanyaan kuesioner ini dimodifikasi dari Parmenter dan Wardle dan sudah dilakukan pengujian reliabilitasnya. Pengembangan dan pengujian kembali pertanyaan dari pengetahuan gizi yang standar dengan membandingkan berbagai subjek dari masyarakat umum dan ahli gizi sendiri perlu dilakukan di masa mendatang. Rentang usia subjek yang lebar dengan sebaran tidak merata pada kelompok umur menyebabkan SSE subjek terpusat pada kelompok menengah ke bawah dengan variasi jumlah subjek cukup besar. Hal ini berdampak pada pengetahuan gizi dan hubungan dengan SSE.

\section{Kualitas Diet}

Skor kualitas diet adalah indeks komposit dari keragaman makanan, kecukupan zat gizi mikro, dan pemenuhan rekomendasi WHO terhadap pencegahan PTM. Keragaman makanan (dietary diversity) berdasarkan jumlah yang dikonsumsi dari sembilan kelompok makanan yaitu pati, kacang-kacangan, sayuran, buah, telur, daging sapi, daging ayam, ikan, dan susu. Rata-rata skor keragamanan makanan $1.93 \pm 0.42$. Pada subjek dengan SSE rendah $1.93 \pm 0.5$, SSE menengah $1.92 \pm 0.4$, SSE tinggi $2.00 \pm 0$.

Proporsi subjek yang memenuhi 75\% dari AKG pada 11 zat gizi mikro sangat rendah kecuali mag- 
Tabel 2. Pengetahuan Gizi Subjek menurut Status Sosial Ekonomi

\begin{tabular}{lccccc}
\hline \multicolumn{1}{c}{ Aspek Pengetahuan } & $\begin{array}{c}\text { Rata-rata } \pm \text { sd } \\
\mathrm{n}=98\end{array}$ & $\begin{array}{c}\text { SSE Rendah } \\
\mathrm{n}=32\end{array}$ & $\begin{array}{c}\text { SSE Menengah } \\
\mathrm{n}=55\end{array}$ & $\begin{array}{c}\text { SSE Tinggi } \\
\mathrm{n}=11\end{array}$ & Nilai $^{2}$ \\
\hline Rekomendasi makan & $9.3 \pm 3.6$ & $8.19 \pm 4.2$ & $9.74 \pm 3.13$ & $11 \pm 3.3$ & $0.042^{*}$ \\
Sumber-sumber zat gizi & $14.0 \pm 11.47$ & $10.12 \pm 11.13$ & $13.7 \pm 10.6$ & $28.36 \pm 4.47$ & $0.000^{*}$ \\
Pemilihan makanan tiap hari & $6.3 \pm 4.96$ & $4.97 \pm 5.09$ & $6.3 \pm 4.67$ & $11.27 \pm 2.6$ & $0.001^{*}$ \\
Hubungan diet dan penyakit & $13.7 \pm 8.6$ & $10.4 \pm 9.08$ & $14.13 \pm 7.57$ & $22.27 \pm 5.4$ & $0.000^{*}$ \\
Total Skor & $43.3 \pm 24.6$ & $33.69 \pm 25.3$ & $43.87 \pm 21.39$ & $72.9 \pm 11.7$ & $0.000^{*}$ \\
\hline
\end{tabular}

nesium $(77.55 \%)$ dan vitamin A $(72.44 \%)$. Sementara asupan vitamin E dan asam folat tidak ada. Proporsi subjek berdasarkan kecukupan zat gizi mikro dapat dilihat pada Tabel 3.

Skor kualitas diet dengan membandingkan tiga indeks agar dapat menggambarkan bukan hanya diet yang seimbang namun diet yang mampu mencegah dari PTM. Skor total kualitas diet sangat rendah dengan rata-rata 7.14 dari maksimal skor 21 (34\%). Skor rata-rata kualitas diet dapat dilihat pada Tabel 4.

Tabel 5 menunjukkan asupan buah dan sayur sangat rendah $259.8 \pm 152.9 \mathrm{~g}$. Hal ini masih dibawah dari minimal $400 \mathrm{~g}$ untuk pencegahan PTM oleh WHO. Konsumsi serat makanan juga masih sangat rendah hanya $8.5 \pm 2.6$ dari minimal $25 \mathrm{~g}$ yang direkomendasikan. Walaupun asupan protein $(\geq 10 \%$ asupan energi), total lemak ( $<30 \%$ asupan energi) dan PUFA (6-10\% asupan energi), kolesterol $(<300$ $\mathrm{mg}$ ) telah memenuhi rekomendasi WHO namun secara skor masih sangat rendah 2.87 dari maksimal skor 11 (26.09\%). Data asam lemak jenuh (<10\% asupan energi) dan asupan sukrosa $(<10 \%$ asupan energi) tidak dapat dihitung karena tidak tersedia dalam daftar komposisi bahan sehingga tidak dapat menilai diet cenderung aterogenik atau tidak.

Keragaman makanan merupakan aspek penting dari diet yang sehat dan seimbang (Ruel 2002) dan hal ini berhubungan dengan kecukupan zat gizi khususnya zat gizi mikro. Pada negara berkembang yang memungkinkan terjadi transisi gizi cenderung akan tinggi lemak jenuh dan gula dan berkurangnya asupan serat.

\section{Hubungan Kualitas Diet, Pengetahuan Gizi, Status Sosial Ekonomi, Status Gizi}

Analisa hubungan pengetahuan gizi, status gizi dan status sosial ekonomi dengan uji Spearman. Rata-rata skor pengetahuan gizi $43.3 \pm 24$.6 dari skor maksimal 131 (33\%). Skor pengetahuan gizi tidak berhubungan dengan IMT, skor dietary diversity, skor pencegahan PTM ( $p>0.05)$, namun berhubungan posistif dengan SSE $(p<0.05)$, total skor kualitas diet, skor kecukupan zat gizi mikro $(p<0.01)$.

SSE umumnya pada kelompok menengah (56.1\%). Tidak ada hubungan antara SSE dengan IMT,

Tabel 3. Sebaran Subjek menurut Tingkat Kecukupan Zat Gizi Mikro dan Status Sosial Ekonomi

\begin{tabular}{lccccc}
\hline \multirow{2}{*}{$\begin{array}{c}\text { Zat Gizi Mikro } \\
\text { (TKG<75\%) }\end{array}$} & $\begin{array}{c}\text { Asupan } \\
\text { (Rata-rata } \pm \text { sd) }\end{array}$ & $\begin{array}{c}\text { Total } \\
\mathrm{n}=98\end{array}$ & $\begin{array}{c}\text { SSE Rendah } \\
\mathrm{n}=32\end{array}$ & $\begin{array}{c}\text { SSE Menengah } \\
\mathrm{n}=55\end{array}$ & $\begin{array}{c}\text { SSE Tinggi } \\
\mathrm{n}=11\end{array}$ \\
\cline { 3 - 6 } & & $\mathrm{n}(\%)$ & $\mathrm{n}(\%)$ & $\mathrm{n}(\%)$ & $\mathrm{n}(\%)$ \\
\hline Kalsium & $272.15 \pm 117.03$ & $2(2.04)$ & 0.00 & $2(3.64)$ & 0.00 \\
Zat besi & $9.6 \pm 4.4$ & $7(7.14)$ & $4(12.50)$ & $3(5.45)$ & 0.00 \\
Magnesium & $260.46 \pm 71.8$ & $76(77.55)$ & $25(78.13)$ & $44(80.00)$ & $7(63.64)$ \\
Seng & $5.8 \pm 1.5$ & $8(8.16)$ & $3(9.38)$ & $4(7.27)$ & $1(9.09)$ \\
Vitamin A & $850 \pm 1062$ & $71(72.44)$ & $21(65.63)$ & $41(74.54)$ & $9(81.82)$ \\
Vitamin C & $26.09 \pm 19.6$ & $5(5.10)$ & $2(6.25)$ & $3(5.45)$ & 0.00 \\
Thiamin & $0.5 \pm 0.15$ & $4(4.08)$ & $1(3.13)$ & $2(3.64)$ & $1(9.09)$ \\
Riboflavin & $0.6 \pm 0.33$ & $14(14.28)$ & $4(12.50)$ & $6(10.90)$ & $4(36.36)$ \\
Vitamin B6 & $0.98 \pm 0.319$ & $40(40.82)$ & $9(28.13)$ & $26(47.27)$ & $5(45.45)$ \\
\hline
\end{tabular}

Tabel 4. Indeks Kualitas Diet berdasarkan Status Sosial Ekonomi

\begin{tabular}{lcccc}
\hline \multicolumn{1}{c}{ Indek Kualitas Diet } & Total & SSE Rendah & SSE Menengah & SSE Tinggi \\
& $\mathrm{n}=98$ & $\mathrm{n}=32$ & $\mathrm{n}=55$ & $\mathrm{n}=11$ \\
\hline Skor keragaman makanan (mak 4) & $11(11.22)$ & $7(21.85)$ & $4(7.27)$ & 0.00 \\
Skor kecukupan zat gizi mikro (mak 11) & $90(91.84)$ & $26(81.25)$ & $53(96.36)$ & $11(100)$ \\
Skor Pencegahan PTM (mak 6) & $45(45.92)$ & $14(43.75)$ & $23(41.82)$ & $8(72.73)$ \\
Total skor (mak 21) & $53(54.08)$ & $15(46.88)$ & 29(52.73) & $9(81.82)$ \\
\hline
\end{tabular}

JGP, Volume 8, Nomor 1, Maret 2013 
Muslihah dkk.

Tabel 5. Sebaran Subjek yang Memenuhi Rekomendasi WHO untuk Pencegahan Penyakit Tidak Menular

\begin{tabular}{llccccc}
\hline Komponen Makanan & \multicolumn{1}{c}{$\begin{array}{c}\text { Rekomendasi WHO } \\
\text { (intake/hari) }\end{array}$} & $\begin{array}{c}\text { Asupan } \\
\text { (Rata-rata } \pm \text { sd) }\end{array}$ & $\begin{array}{c}\text { Total } \\
\mathrm{n}=98\end{array}$ & $\begin{array}{c}\text { SSE Rendah } \\
\mathrm{n}=32\end{array}$ & $\begin{array}{c}\text { SSE Menengah } \\
\mathrm{n}=55\end{array}$ & $\begin{array}{c}\text { SSE Tinggi } \\
\mathrm{n}=11\end{array}$ \\
\hline Buah dan sayuran & $\geq 400 \mathrm{~g}$ & $259.8 \pm 152.9$ & $11(11.22)$ & $7(21.85)$ & $4(7.27)$ & 0 \\
Protein & $\geq 10 \%$ intake energi & $12.9 \pm 2.6$ & $90(91.84)$ & $26(81.25)$ & $53(96.36)$ & $11(100)$ \\
Total lemak & $<30 \%$ intake energi & $28.9 \pm 6.9$ & $45(45.92)$ & $14(43.75)$ & $23(41.82)$ & $8(72.73)$ \\
PUFA & $6-10 \%$ intake energi & $8.6 \pm 2.5$ & $53(54.08)$ & $15(46.88)$ & $29(52.73)$ & $9(81.82)$ \\
Kolesterol & $<300 \mathrm{mg}$ & $149.4 \pm 151.03$ & $86(87.76)$ & $29(90.63)$ & $47(85.45)$ & $8(72.73)$ \\
Serat makanan & $\geq 25 \mathrm{~g}$ & $8.5 \pm 2.6$ & 0.00 & 0.00 & 0.00 & 0.00 \\
\hline
\end{tabular}

skor keragamanan pangan, kecukupan zat gizi mikro, dan skor pencegahan PTM rekomendasi WHO ( $p>0.05)$ namun hanya berhubungan dengan pengetahuan gizi $(p<0.05)$.

Status gizi dengan indikator IMT tidak berhubungan dengan pengetahuan gizi, SSE, kecukupan zat gizi mikro, dan pencegahan PTM ( $p>0.05)$, namun hanya berhubungan dengan skor dietary diversity $(p<0.05)$. Skor total kualitas diet tidak ada hubungan dengan IMT dan SSE ( $p>0.05)$, namun berhubungan dengan pengetahuan gizi $(p<0.01)$. Penelitian lainnya yang dilakukan pada kelompok sasaran anak menyimpulkan terdapat hubungan yang positif antara status gizi dengan pendapatan per kapita $(p<0.05)$ (Marut 2007).

\section{KESIMPULAN}

Skor kualitas diet dan pengetahuan gizi masih rendah, hal ini karena masih lebarnya rentang usia subjek yang berpengaruh terhadap status sosial ekonomi. Kualitas diet hanya berhubungan dengan pengetahuan gizi namun tidak dengan IMT dan SSE. Konsumsi sayuran dan buah serta serat makanan masih sangat rendah dibawah rekomendasi WHO untuk pencegahan PTM.

Penelitian lebih lanjut tentang kualitas diet perlu dilakukan berdasarkan kelompok umur dewasa 25-39 tahun dan 40-64 tahun karena berbedanya masa produktif bekerja dan gaya hidup; wilayah perkotaan-perdesaan, dan suku. Indikator kualitas diet dan instrumen pengetahuan gizi perlu dikembangkan.

\section{DAFTAR PUSTAKA}

Institute of Medicine Food and Nutrition Board.1998. Dietary Reference intake for Thiamin, Riboflavin, Niacin, Vitamin B6, Folate, Vitamin B12, Panthothenic acid, Biotin, and Cholin. National Academy Press, Washington DC.

Institute of Medicine Food and Nutrition Board. 2000.
Dietary Reference intake for Vitamin C, Vitamin E, Selenium, and Carotenoid. National Academy Press, Washington DC.

Kim S, Haines PS, Siega-Riz Am, \& Popkin B. 2003. The diet quality index-international (DQI-I) provides an effective tool for cross-national comparison of diet quality as illustrated by China and the United States. J Nutr, 133, 3476-84.

Marut UD. 2007. Aspek Sosial ekonomi dan Kaitannya dengan Masalah Gizi Kurang di Kabupaten Manggarai, Nusa Tenggara Timur. Jurnal Gizi dan pangan, 2(3), 36-43.

Parmenter K \& J Wardle. 1999. Development of a general nutrition knowledge questionnaire for adults. European Journal of clinical Nutrition, 53, 298-308.

Ponce X, Ramirez E, \& Delisle H. 2006. A More Diversified diet among Mexican Men Also Be More Atherogenic. Journal Nutrition 136, 2921-2927.

Popkin, BM. 2002. An overview on the nutrition and its health implications: the Bellagio meeting. Public Health Nutr, 5, 93-103.

Ruel MT. 2002. Is dietary diversity an indicator of food security or dietary quality? A review of measurement issues and research needs. $\mathrm{Pa}$ per No. 140. 2002, International Food Policy Research Institute, Washington DC.

World Health Organization (WHO), Food and Agriculture Organization (FAO). 1996. Preparation and use of food based dietary guidelines. Report of a Joint FAO/WHO; Nicosia Cyprus.

World Health Organization. 2002. World Health Report 2002: Reducing risks, promoting healthy life. WHO, Geneva, Switzerland.

World Health Organization (WHO), Food and Agriculture Organization (FAO). 2003. Diet, Nutrition and Prevention of chronic Diseases. Report of a joint WHO/FAO expert consultation. Report no. 916. WHO, Geneva, Switzerland. 